University of Nebraska - Lincoln

DigitalCommons@University of Nebraska - Lincoln

September 2002

\title{
LARVAL DESCRIPTIONS FOR THE NEOTROPICAL GENUS PLATYCOELIA (COLEOPTERA: SCARABAEIDAE: RUTELINAE: ANOPLOGNATHINI)
}

\author{
Aura Paucar C. \\ University of Nebraska State Museum, aurapc@unlserve.unl.edu \\ Andrew Smith \\ asmith@unl.edu
}

Follow this and additional works at: https://digitalcommons.unl.edu/entomologypapers

Part of the Entomology Commons

Paucar C., Aura and Smith, Andrew, "LARVAL DESCRIPTIONS FOR THE NEOTROPICAL GENUS PLATYCOELIA (COLEOPTERA: SCARABAEIDAE: RUTELINAE: ANOPLOGNATHINI)" (2002). Papers in Entomology. 18.

https://digitalcommons.unl.edu/entomologypapers/18

This Article is brought to you for free and open access by the Museum, University of Nebraska State at DigitalCommons@University of Nebraska - Lincoln. It has been accepted for inclusion in Papers in Entomology by an authorized administrator of DigitalCommons@University of Nebraska - Lincoln. 


\title{
Larval Descriptions for the Neotropical Genus Platycoelia (COLEOPTERA: ScarabaEIDAE: RutelinaE: ANOPlogNathini)
}

\author{
Aura Paucar-Cabrera And Andrew B. T. Smith ${ }^{1}$ \\ W436 Nebraska Hall, Division of Entomology, \\ University of Nebraska State Museum, \\ Lincoln, NE 68588-0514, U.S.A.
}

\begin{abstract}
The larvae of Platycoelia gaujoni Ohaus and Platycoelia lutescens Blanchard (Coleoptera: Scarabaeidae: Rutelinae) are described. These are the first descriptions of Neotropical Anoplognathini larvae. The character states shared by larval Platycoelia and two previously described Australian Anoplognathini larvae are examined. Character states that separate known Anoplognathini larvae from other Rutelinae tribes are also discussed.
\end{abstract}

\section{Resúmen}

Se describen las larvas de Platycoelia gaujoni Ohaus y Platycoelia lutescens Blanchard (Coleoptera: Scarabaeidae: Rutelinae). Esta es la primera descripción de las larvas de Anoplognathini neotropicales. Se examinan los estados de los caracteres compartidos entre las larvas de Platycoelia y las larvas de dos especies australianas de Anoplognathini, previamente descritas. Se discuten los estados de los caracteres que distinguen a las larvas de los Anoplognathini conocidos de otras tribus de Rutelinae.

The genus Platycoelia Dejean (Coleoptera: Scarabaeidae: Rutelinae) contains 62 species that occur from central México to northern Argentina (Smith 2002). Most species are distributed in mid-elevation habitats $(1,000-2,500 \mathrm{~m})$ from Colombia to Bolivia. Until now, there were no published descriptions of Platycoelia larvae. We describe here the larvae of $P$. gaujoni Ohaus (found in Ecuador) and P. lutescens Blanchard (found in Colombia, Ecuador, and Perú), the first Neotropical Anoplognathini larvae to be described.

Although the subfamily Rutelinae is diverse (with approximately 4,000 described species [Machatschke 1972]), relatively few descriptions of larvae have been published. This is especially true of the Anoplognathini. This tribe contains over 150 described species yet the larvae of only two species in two genera have been described. Hardy (1976) described larvae of Saulostomus villosus Waterhouse from Tasmania, Australia. McQuillan (1985) redescribed the larvae of S. villosus and described larvae of Anoplognathus suturalis Boisduval from Tasmania. Additional larval descriptions of Anoplognathini are needed to help corroborate or refute current hypotheses of within group relationships to provide a foundation for future taxonomic studies, and for reliable identifications of root-feeding larvae. This research complements the recent taxonomic work on Platycoelia by Smith and Paucar-Cabrera (2000) and Smith (2002).

Ohaus $(1908,1909)$ recorded the first observations of Platycoelia larvae from Loja, Ecuador. He stated that the larvae of P. gaujoni were found under fallen logs and that they feed on the organic matter in the soil. Specimens that Ohaus collected

\footnotetext{
${ }^{1}$ Email: asmith@unlserve.unl.edu
} 
were used in our description. Ritcher $(1948,1966)$ provided a larval key to the tribes of Rutelinae (excluding Geniatini and Spodochlamyini). Although there were no published descriptions of Anoplognathini larvae at the time, Ritcher (1948, 1966) did include the tribe in his key. Ritcher (1966) stated that Anoplognathini "are found in Mexico, Central America, and South America." Ritcher's omission of Australia probably indicates that only Neotropical larvae were examined for his analysis. Hardy (1976) and McQuillan (1985) provided the only formal descriptions of Anoplognathini larvae using Saulostomus villosus and Anoplognathus suturalis. These two species were selected because they "live and feed in the root zone of pastures in Tasmania."

Our descriptions of two species of Platycoelia will significantly broaden the knowledge of the larvae of this tribe. However, many more taxa need to be examined before relationships within the Anoplognathini based on larval characters can be synthesized in a meaningful way. The preliminary state of knowledge of Rutelinae larvae makes accurate identification tenuous at best. The larvae of only one species of Adoretini has been described (Adoretus sinicus Burmeister by Habeck 1963) and the larvae of Geniatini and Spodochlamyini are completely unknown. Larvae of the tribe Rutelini (Jameson and Morón 2001) are relatively well known, and a limited number of Anomalini genera and species have been described (Ritcher 1966).

\section{Diagnostic Characters for Anoplognathini Larvae}

The characters used in Ritcher's (1966) key to distinguish Anoplognathini larvae were apical antennal segment with a single, dorsal sensory spot; haptomerum of epipharynx with a beak-like process; and palidia absent. The four known larvae of Anoplognathini all have one dorsal sensory spot on the last antennal segment, including the larvae we describe herein. This character state is shared with known Anomalini and Adoretini larvae. The "beak-like" process of the epipharynx mentioned by Ritcher (1966) refers to the prominent, sclerotized epizygum. This character state is shared with some Rutelini larvae. The palidia are absent from both Platycoelia and Anoplognathus suturalis but are present in Saulostomus villosus (McQuillan 1985). The four known larvae of Anoplognathini key out to the Dynastinae using Ritcher's (1966) key to subfamilies of Scarabaeidae based on larval characters (because the maxillary lacinia have three well-developed terminal unci and the plegmatia are absent). There is no current key to the families, subfamilies, and tribes of Scarabaeoidea based on larval characters that will identify Anoplognathini larvae.

More species of Anoplognathini larvae will need to be discovered and described before a complete set of diagnostic characters can be listed for the tribe. Based on the four known larvae of Anoplognathini, the tribe can be identified using the following combination of characters: apical antennal segment with single, dorsal sensory spot; labrum asymmetrical; haptomerum of epipharynx with beak-like process, weak row of basal heli, or process entirely absent; mandible with ventral, oval, stridulatory area consisting of transverse ridges; maxilla with galea and lacina fused forming mala; lacinia of maxilla with 3 well-developed terminal unci; maxillary stridulatory area with 6-11 sharp, recurved teeth; anal slit straight or slightly curved.

\section{Specimens}

Specimens were borrowed from and deposited in the following institutions:

QCAZ Museo de Zoología, Pontificia Universidad Católica del Ecuador, Quito, Ecuador (Giovanni Onore) 

UNSM University of Nebraska State Museum, Lincoln, NE (Brett Ratcliffe, Mary Liz Jameson)
ZMHB Museum für Naturkunde der Humboldt-Universität zu Berlin, Germany (Hella Wendt)

\title{
Platycoelia gaujoni Ohaus, third-instar larva
}

\author{
Figs. 1-9
}

The larval description of Platycoelia gaujoni is based on 1 third-instar larva. This specimen is associated with two second-instar larvae with the following collecting data: Ecuador, Loja, Villonaco, 3,000 m, 5 September 1905, F. Ohaus. Ohaus (1908, 1909) discussed these specimens and also collected several adults during his travels in Ecuador. His species determination for these larvae was based on associated adult specimens collected in the same locality. Specimens are housed at ZMHB.

Description. Width of head capsule $5.0 \mathrm{~mm}$. Cranium (Fig. 2). Color of epicranium, clypeus, labrum reddish-brown; frons reddish-brown with anterior frontal angles black; mandibles reddish-brown with apex black. Surface of epicranium finely rugose, with 2 short, basal setae; 10 short to long, lateral setae; 2 moderately long, dorsoepicranial setae. Frons finely rugose basally, gradually becoming sparsely punctate apically; with 1 anterior frontal angle seta, 1 posterior frontal seta, 1 anterior frontal seta at each side. Clypeus (Fig. 2). Shape subtrapezoidal. Surface rugopunctate, punctures sparse. With 2 moderately long, anterior clypeal setae; 2 moderately long, exterior clypeal setae. Labrum (Fig. 2). Form subovate, symmetrical. Base with 2 short setae, disc with 3-4 moderately long setae, margin with 2-3 moderately long setae, subapex with approximately 7 moderately long setae. Epipharynx (Fig. 3). Form suboval. Plegmata absent. Corypha with 4 moderately long, thick setae. Acanthoparia with 11-12 short, sickleshaped setae. Chaetoparia with approximately 31 moderately long, thick setae (left side); approximately 38 moderately long, thick setae on disc; approximately 13 short, thick setae on base (right side). Acroparia with 9 long, thick setae. Dexiotorma long, pternotorma weakly developed. Laeotorma long, shorter than desiotorma, with pternotorma well-developed. Sensory cone well-developed, equal in size to left pternotorma. Epizygum sclerotized, prominent. Haptomerum with approximately 8 heli. Mandibles. Left mandible (Figs. 6a, 7b). Scissorial region with 3 teeth. Dorsal surface with 9 long setae at external margin; 9 dorsomolar setae; 3-4 short, dorsoexterior setae. Molar area with 2 lobes, acia elongate. Basomolar region with 13 moderately long setae. Stridulatory area suboval, with approximately 40 ridges. Ventral process welldeveloped. Ventral-exterior region with 5-6 short, thick setae laterad of stridulatory area. Right mandible (Figs. 6b, 7a). Scissorial region with 3 teeth. Molar area trilobed. Dorsal surface with 10 dorsomolar setae. Calx prominent, with 6 thick setae. Ventral surface with suboval stridulatory area with approximately 40 ridges. Ventral process well-developed. Ventral-exterior region with 5-6 short, thick setae laterad of stridulatory area. Lateral surface with 8 long setae. Maxilla (Fig. 5). Galea with 1 uncus; ventral surface with 5-6 short, thick setae. Palpus 4-segmented. Lacinia with 3 sharp unci, 20 moderate to long setae. Stipes with 11 short stridulatory teeth. Truncate process present. Cardo with approximately 4-5 long setae. Hypopharynx (Fig. 4). Hypopharyngeal sclerome asymmetrical, right side with raised truncate process. Left lateral lobe with approximately 11 moderately long setae. Apex of glossa with 4 moderately long setae; disc of glossa with 13 unciform, thick setae mixed with 8-10 moderately long setae. Labium. Apex with approximately 8 short setae. Prementum I with 6 short, 2 long, thin setae. Prementum II with 3 short, lateral setae. Labial palpus 2-segmented. Antenna. 4 segmented. Apical segment with 1 dorsal sensory spot, 3 ventral sensory spots. Second segment 1.7 times longer than first segment. Apical segment with acute apex; third segment with elongate process at apex. Spiracles (Fig. 8). Respiratory plate C-shaped, surrounding flattened bulla; distance between respiratory lobes less than diameter of bulla; plate with approximately 16 holes across diameter, holes suboval. Thoracic spiracle $0.3 \mathrm{~mm}$ wide, $0.4 \mathrm{~mm}$ high, length slightly shorter than first abdominal spiracle. Abdominal spiracles 1-8 subequal in length. Abdominal spiracles 4-8 round, slightly wider than abdominal spiracles 1-3. Dorsal body vestiture (Fig. 1). First thoracic segment with 32 short to moderate, slender setae. Second thoracic segment with 22 

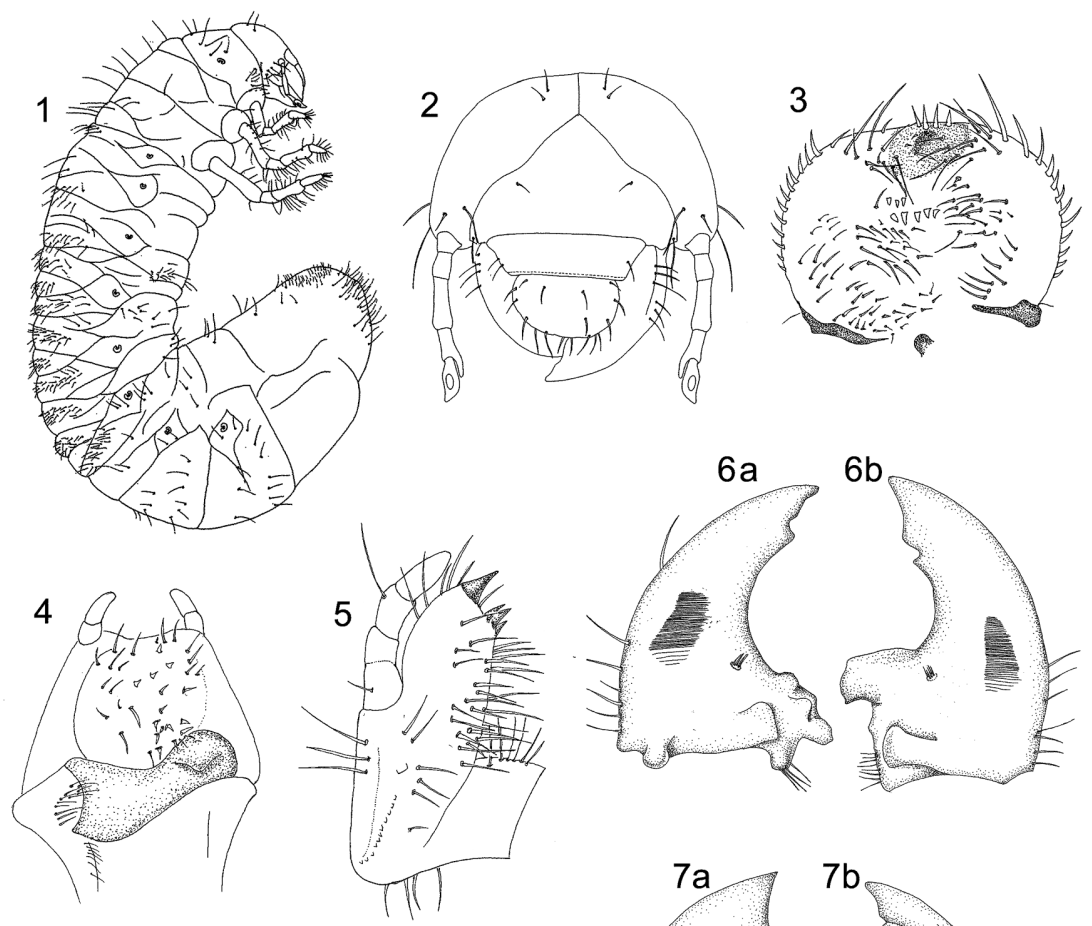

8

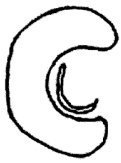

9

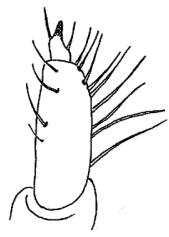

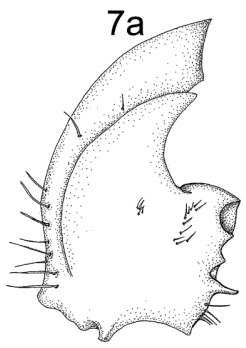

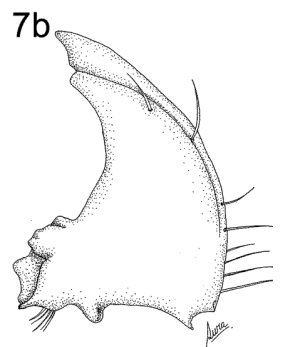

Figs. 1-9. Platycoelia gaujoni third instar larva. 1) Habitus; 2) frontal view of head; 3) epipharynx; 4) labium and hypopharynx; 5) dorsal view of maxilla; 6) ventral view of a) right mandible and b) left mandible; 7) dorsal view of a) left mandible and b) right mandible; 8) thoracic spiracle; 9) tarsungulus of posterior leg.

short to long, slender setae. Third thoracic segment with 34 short to long, slender setae. Abdominal segment I with 2 short setae mixed with 9 long, slender setae. Abdominal segment II with 40 short, thick setae mixed with 18 long setae. Abdominal segment III with 54 short, thick setae mixed with 22 long, slender setae. Abdominal segment IV with 96 short, thick setae mixed with 16 long, slender setae. Abdominal segment V with 112 short, thick setae mixed with 28 long, slender setae. Abdominal segment VI with 134 short, thick setae mixed with 1016 long, slender setae. Abdominal segment VII with 12 short, slender setae mixed with 44 moderate to long, slender setae. Abdominal segment VIII with 20 long, slender setae. Abdominal segment IX with 11 long, slender setae mixed with 3 short, thin setae. Abdominal segment $\mathrm{X}$ with approximately 90 moderate to long, slender setae mixed with 20 short, slender setae. Pleural lobes with 2-10 short to long, slender setae. Venter. First to third thoracic segments each with 18-24 moderate, slender setae; abdominal segments each with 4-22 short to moderate, slender setae. Raster. Anal slit slightly bisinuate. Dorsal anal lobe with approximately 30 
short, sparse setae mixed with 20 moderately long setae. Lower anal lobe with approximately 48 hamate setae; ventral anal slit area with approximately 32 short to moderate, slender setae. Palidia absent; tegilla with approximately 48 hamate setae mixed with 6 moderate to long, slender setae; campus with 4 moderately long, thin setae. Barbula with 9 moderate to long, slender setae at each side. Legs (Fig. 1). Length 4.9-8.0 mm (legs gradually increasing in size from prothoracic to metathoracic leg). Coxae, trochanters, and femora with 36-53 moderate to long, slender setae; tibiotarsus with 12-18 moderately long setae. Tarsunguli of prothoracic, mesothoracic, metathoracic (Fig. 9) legs well-developed, with 1 prebasal seta, 1 preapical seta, 4-5 distotarsal setae.

Remarks. Platycoelia gaujoni differs from $P$. lutescens by the following combination of characters: epipharynx with laeotorma shorter than dexiotorma (Fig. 3) (longer than dexiotorma in P. lutescens); mandible with three scissorial teeth (Figs. 6a-b, $7 \mathrm{a}-\mathrm{b}$ ) (two scissorial teeth in $P$. lutescens); abdominal spiracles round (elongate in P. lutescens).

\section{Platycoelia lutescens Blanchard, third-instar larva}

Figs. 10-19

The larval description of Platycoelia lutescens is based on three third-instar larvae with the following collecting data: Ecuador, Pichincha, Santa Catalina, 3,300 m, 29 October 1993, G. Onore. Larvae are associated with one adult (reared by Giovanni Onore). Two specimens are housed at QCAZ and one at UNSM. The natural history of $P$. lutescens was outlined by Smith and Paucar-Cabrera (2000).

Description. Width of head capsule 6.0-6.3 mm. Cranium (Fig. 11). Color of epicranium yellowish-brown with reddish-brown coronal suture; frons yellowish-brown with black anterior frontal angles; clypeus yellowish-brown to reddish-brown; labrum yellowish-brown (with or without reddish-brown, rounded macula at mid-apex) or entirely black; mandibles yellowishbrown to reddish-brown at base, disc with external margins, apex black. Surface of epicranium finely rugose, with 6 short, basal setae; 4-5 long, lateral setae; 2 short, dorsoepicranial setae. Frons finely rugose basally, rugopunctate apically; with 1 seta at each anterior angle. Clypeus (Fig. 11). Shape subtrapezoidal. Base of clypeus weakly rugopunctate; preclypeus smooth, with 2 short, exterior setae. Labrum (Fig. 11). Form subovate, symmetrical. Base with 2 short setae, disc with 3-4 short setae at each side, margin with 2 moderately long setae, subapex with 1113 moderately long to short setae. Epipharynx (Fig. 12). Form suboval. Plegmata absent. Corypha with 2 short and 2 long, thick setae. Acanthoparia with 13-15 short, sickle-shaped setae. Chaetoparia with approximately 15 short, thick setae on apex (left side); approximately 55 moderate setae from middle to base (left side); approximately 8 short, thick setae on apex (right side), approximately 48 moderately long setae from middle to base (right side). Acroparia with 10 moderately long, thick setae. Dexiotorma long, pternotorma weakly developed. Laeotorma long, expanded towards chaetoparia, with pternotorma well-developed. Sensory cone well developed, equal in size to left pternotorma. Epizygum sclerotized, prominent. Haptomerum with approximately 13 short, thick heli. Mandibles. Left mandible (Figs. 15a, 16b). Scissorial region with 2 teeth. Dorsal surface with 4 long setae at external margin. Molar area with 3 lobes; acia elongate, sickle-shaped. Basomolar region with 5 moderately long setae. Stridulatory area suboval, with approximately 40 ridges. Ventral process well-developed. Ventral-exterior region with 5-7 short, thick setae laterad of stridulatoy area. Right mandible (Figs. 15b, 16a). Scissorial region with 2 teeth. Molar area with 4 lobes. Calx prominent, with 6 thick setae. Ventral surface with suboval stridulatory area comprised of approximately 30-35 ridges. Lateral surface with 5 long setae. Maxilla (Fig. 14). Galea with 1 uncus, ventral surface with 5-6 short, thick setae. Palpus 4-segmented. Lacinia with 3 unci, 14 moderate to long setae. Stipes with 11 quadrate, short stridulatory teeth. Truncate process present. Cardo with approximately 5-6 long setae. Hypopharynx (Fig. 13). Hypopharyngeal sclerome weakly asymmetrical, right side with raised truncate process. Right lateral lobe with 1 moderate, thick seta; left lateral lobe with approximately 14 moderately long setae. Apex of glossa with 2 long setae; disc of glossa with 18-20 unciform, thick setae; discal sides with 25-30 moderately long, thick setae. Labium. 


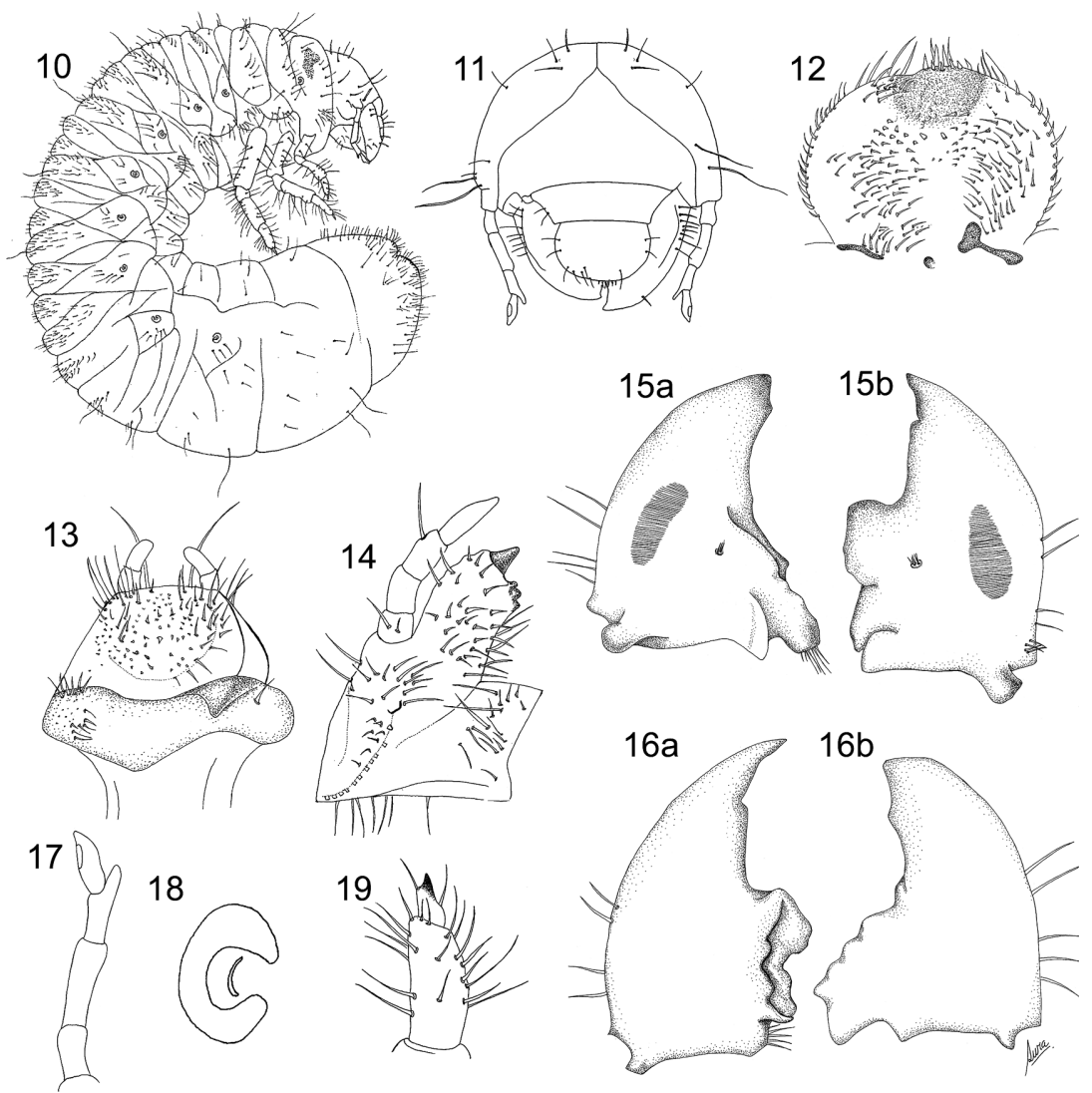

Figs. 10-19. Platycoelia lutescens third instar larva. 10) Habitus; 11) frontal view of head; 12) epipharynx; 13) labium and hypopharynx; 14) dorsal view of maxilla; 15) ventral view of a) right mandible and b) left mandible; 16) dorsal view of a) left mandible and b) right mandible; 17) dorsal view of antenna; 18) thoracic spiracle; 19) tarsungulus of posterior leg.

Apex with 6 short setae. Prementum I with 2 short, lateral setae. Prementum II with 2-3 short, lateral setae. Labial palpus 2-segmented. Antenna. 4 segmented. Apical segment with 1 dorsal sensory spot, 1 ventral sensory spot. Second segment 1.3 times longer than first segment. Apical segment with apex acute; third segment with elongate process at apex (Fig. 17). Spiracles (Fig. 18). Respiratory plate C-shaped, surrounding flattened bulla; distance between respiratory lobes less than diameter of bulla; plate with approximately 16 holes across diameter, holes suboval. Thoracic spiracle $0.4-0.5 \mathrm{~mm}$ wide, $0.6-0.7 \mathrm{~mm}$ high, subequal in size to first abdominal spiracle. Abdominal spiracles 1-8 similar in width. Dorsal body vestiture (Fig. 10). First thoracic segment with 26-30 short to moderate, slender setae. Second thoracic segment with 30-34 short to moderate, slender setae. Third thoracic segment with 34-44 short to moderate, slender setae. Abdominal segment I with 20-28 short, thick, moderately dense setae; 6-8 moderately long, slender setae mixed with 2-6 long, slender setae. Abdominal segment II with 80-96 short, thick, moderately dense setae; 3-5 moderately long, slender setae mixed with 4-6 long, slender, crimped setae. Abdominal segment III with 124-162 short, thick, moderately dense setae; 5-10 moderately long, slender setae mixed with 4-6 long, slender, crimped setae. Abdominal segment IV with 154-186 short, thick, moderately dense setae; 21-27 moderately long, slender 
setae mixed with 7-11 long, slender, crimped setae. Abdominal segment V with 198-230 short, thick, moderately dense setae; 16-28 moderately long, slender setae mixed with 14-18 long, slender, crimped setae. Abdominal segment VI with 192-210 short, thick, moderately dense setae; 18-24 moderately long, slender setae mixed with 10-16 long, slender, crimped setae. Abdominal segment VII with 38-46 short, thick, moderately dense setae; 14-20 moderately long, slender setae mixed with 6-8 long, slender, crimped setae. Abdominal segment VIII with 1214 moderately long, slender, sparse setae mixed with 6-8 long, slender, crimped setae. Abdominal segment IX with 12-26 moderately long, slender, sparse setae mixed with 8-10 long, slender, crimped setae. Abdominal segment $X$ with 72-100 moderately long, slender setae mixed with 4 long, slender, crimped setae; 40-54 short, thick, moderately dense setae at apex. Pleural lobe of first abdominal segment glabrous, abdominal segments II-VIII with 3-8 short to moderately long, sparse setae. Venter. First and second thoracic segments each with 40-46 moderate setae, third thoracic segment with 12-14 moderately long setae; abdominal segments with 4-12 moderately long setae. Raster. Anal slit weakly bisinuate. Dorsal anal lobe with approximately 30 short, moderately dense setae mixed with 10 moderately long setae. Lower anal lobe with approximately 30 hamate setae; ventral anal slit area with approximately 14 moderately long, slender setae. Palidia absent; tegilla with approximately 98 hamate setae; campus with 8 moderately long, thin setae. Barbula with 5 long, slender setae. Legs (Fig. 10). Length $3.8-7.1 \mathrm{~mm}$ (legs gradually increasing in size from prothoracic to metathoracic leg). Coxae, trochanters, and femora with 38-60 moderate to long, slender setae; tibiotarsus with 20-25 moderately long setae. Tarsunguli of prothoracic, mesothoracic, metathoracic legs (Fig. 19) well developed; with 1 prebasal seta, 1 preapical seta, 6-7 distotarsal setae.

Remarks. Platycoelia lutescens differs from P. gaujoni by the following combination of characters: epipharynx with laeotorma longer than dexiotorma, expanded towards chaetoparia (Fig. 12) (laeotorma shorter than dexiotorma in P. gaujoni); mandible with two scissorial teeth (Figs. 15a-b, 16a-b) (three scissorial teeth in $P$. gaujoni); abdominal spiracles elongate (round in $P$. gaujoni).

\section{Acknowledgments}

We thank Giovanni Onore (Museo de Zoología, Pontificia Universidad Católica del Ecuador, Quito, Ecuador) and Hella Wendt (Museum für Naturkunde der HumboldtUniversität zu Berlin, Germany) for the loans of larval specimens used for our research. Thanks to Brett Ratcliffe and Mary Liz Jameson (University of Nebraska State Museum, Lincoln, NE) for reviewing the manuscript. This project was supported, in part, by an NSF/PEET grant (DEB-9712447) to B. Ratcliffe and M. Jameson.

\section{Literature Cited}

Habeck, D. H. 1963. Descriptions of immature stages of the Chinese rose beetle, Adoretus sinicus Burmeister (Coleoptera: Scarabaeidae). Proceedings of the Hawaiian Entomological Society 18:251-258.

Hardy, R. J. 1976. Observations on the pasture beetle, Saulostomus villosus Waterhouse (Scarabaeidae: Rutelinae). Journal of the Australian Entomological Society 15:281-284.

Jameson, M. L., and M. A. Morón. 2001. Descriptions of the larvae of Chlorota cincticollis Blanchard and Chasmodia collaris (Blanchard) (Scarabaeidae: Rutelinae: Rutelini) with a key to the larvae of the American genera of Rutelini. Coleopterists Bulletin 55:385396.

Machatschke, J. W. 1972. Scarabaeoidea: Melolonthidae, Rutelinae. Coleopterorum Catalogus Supplementa 66(1):1-361.

McQuillan, P. B. 1985. The identification of root-feeding cockchafer larvae (Coleoptera: Scarabaeidae) found in pastures in Tasmania. Australian Journal of Zoology 33:509-546.

Ohaus, F. 1908. Die Ruteliden meiner Sammelreisen in Südamerika (Col.). Deutsche Entomologische Zeitschrift 1908:383-408.

Ohaus, F. 1909. Bericht über eine entomologische Studienreise in Südamerika. Entomologische Zeitung 70:87-99. 
Ritcher, P. O. 1948. Description of the larvae of some ruteline beetles with keys to tribes and species. Annals of the Entomological Society of America 41:206-212.

Ritcher, P. O. 1966. White grubs and their allies. Oregon State University Press, Corvallis, OR. 219 pp.

Smith, A. B. T. 2002. A monographic revision of the genus Platycoelia Dejean (Coleoptera: Scarabaeidae: Rutelinae: Anoplognathini). Bulletin of the University of Nebraska State Museum, submitted.

Smith, A. B. T., and A. Paucar-Cabrera. 2000. Taxonomic review of Platycoelia lutescens (Scarabaeidae: Rutelinae: Anoplognathini) and a description of its use as food by the people of the Ecuadorian highlands. Annals of the Entomological Society of America 93:408-414.

(Received 23 December 2001; accepted 13 May 2002. Full page charges borne by the authors.) 